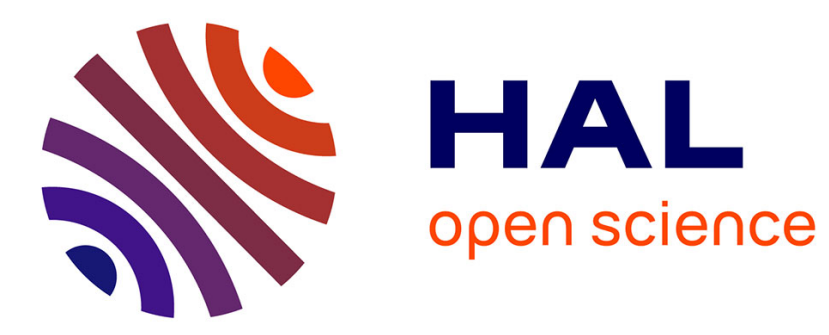

\title{
How Ebola impacts social dynamics in gorillas: a multistate modelling approach.
}

Céline Genton, Romane Cristescu, Sylvain Gatti, Florence Levréro, Elodie

Bigot, Peggy Motsch, P. Le Gouar, Jean-Sébastien Pierre, Nelly Ménard

\section{- To cite this version:}

Céline Genton, Romane Cristescu, Sylvain Gatti, Florence Levréro, Elodie Bigot, et al.. How Ebola impacts social dynamics in gorillas: a multistate modelling approach.. Journal of Animal Ecology, 2015, 84 (1), pp.166-76. 10.1111/1365-2656.12268 . hal-01579437

\section{HAL Id: hal-01579437 \\ https://hal-univ-rennes1.archives-ouvertes.fr/hal-01579437}

Submitted on 31 Aug 2017

HAL is a multi-disciplinary open access archive for the deposit and dissemination of scientific research documents, whether they are published or not. The documents may come from teaching and research institutions in France or abroad, or from public or private research centers.
L'archive ouverte pluridisciplinaire HAL, est destinée au dépôt et à la diffusion de documents scientifiques de niveau recherche, publiés ou non, émanant des établissements d'enseignement et de recherche français ou étrangers, des laboratoires publics ou privés. 
Using demographic characteristics of populations to detect spatial fragmentation following suspected Ebola outbreaks in great apes.

Céline Genton ${ }^{1 \$}$, Romane Cristescu ${ }^{2 \$}$, Sylvain Gatti ${ }^{1}$, Florence Levréro ${ }^{3}$, Elodie Bigot ${ }^{1}$, Peggy Motsch $^{1}$, Pascaline Le Gouar ${ }^{1}$, Jean-Sébastien Pierre ${ }^{4}$, Nelly Ménard ${ }^{1}$

${ }^{1}$ UMR 6553, ECOBIO: Ecosystems, Biodiversity, Evolution, CNRS/University of Rennes 1, Biological Station of Paimpont, Paimpont, France,

${ }^{2}$ GeneCology Research Centre, Faculty of Science, Health, Education and Engineering, University of the Sunshine Coast, Sippy Downs, QLD, Australia,

${ }^{3}$ Université de Saint-Etienne/Lyon, Equipe de Neuro-Ethologie Sensorielle, Neuro-PSI, CNRS UMR 9197, Saint-Etienne, France,

${ }^{4}$ UMR 6553, ECOBIO: Ecosystems, Biodiversity, Evolution, CNRS/University of Rennes 1, Rennes, France

\$: These authors contributed equally to this work.

Institution from which the paper emanated: CNRS/University of Rennes1 - UMR 6553, ECOBIO, Biological Station, 35380 Paimpont, France.

Abbreviated title : Ebola and spatial structuring of great apes

Key words: Western lowland gorilla, emerging disease, demography, population fragmentation.

Corresponding author: Nelly Ménard, UMR 6553, ECOBIO: Ecosystems, Biodiversity, Evolution, CNRS/University of Rennes 1, Biological Station of Paimpont, Paimpont, France, Tel.: 33(2)99618172, nelly.menard@univ-rennes1.fr

Grant sponsorship: ANR-11-JVS7-015 for the project IDi-Pop 


\begin{abstract}
Objectives

Demographic crashes due to emerging diseases can contribute to population fragmentation and increase extinction risk of small populations. Ebola outbreaks in 2002-2004 are suspected to have caused a decline of more than $80 \%$ in some Western lowland gorilla (Gorilla gorilla gorilla) populations. We investigated whether demographic indicators of this event allowed for the detection of spatial fragmentation in gorilla populations.
\end{abstract}

\title{
Materials and Methods:
}

We collected demographic data from two neighbouring populations: the Lokoué population, suspected to have been affected by an Ebola outbreak (followed from 2001-2014), and the Romani population, of unknown demographic status before Ebola outbreaks (followed from 2005-2014).

\section{Results}

Ten years after the outbreak, the Lokoué population is slowly recovering and the short-term demographic indicators of a population crash were no longer detectable. The Lokoué population has not experienced any additional demographic perturbation over the past decade. The Romani population did not show any of the demographic indicators of a population crash over the past decade. Its demographic structure remained similar to that of unaffected populations.

\section{Discussion}

Our results highlighted that the Ebola disease could contribute to fragmentation of gorilla populations due to the spatially heterogeneous impact of its outbreaks. The demographic structure of populations (i.e. age-sex and group structure) can be useful indicators of a possible occurrence of recent Ebola outbreaks in populations without known history, and may be more broadly used in other emerging disease/species systems. Longitudinal data are critical 
to our understanding of the impact of emerging diseases on wild populations and their conservation. 
Emerging diseases have caused local declines or extinctions of populations in a variety of species, including birds (LaDeau et al., 2007), mammals (Hawkins et al., 2006) and amphibians [see a review in (Kilpatrick et al., 2010)] and can contribute to the fragmentation of populations at broad regional scales (Vredenburg et al., 2010). The spatial emergence of a disease and its extent thus represent critical information for conservation management (Bode et al., 2009; McCallum and Dobson, 1995).

The Ebola virus threats to Western lowland gorilla (Gorilla gorilla gorilla) populations led the International Union for Conservation of Nature (IUCN) to classify the species as “critically endangered" (IUCN, 2008). The conditions for the emergence and subsequent spreading of the Ebola virus through gorilla populations are not fully understood. Although three bat species appear to be the best reservoir candidate for the local persistence of the virus in the environment (Leroy et al., 2005), other intermediate hosts or unknown reservoirs remain possible (Leendertz et al., 2016). Ebola outbreaks in great apes are suspected to result from multiple virus introductions from widely dispersed natural reservoirs (Grard et al., 2011; Leroy et al., 2004; Wittmann et al., 2007). Multiple spillovers could lead to a heterogeneous spatial impact of the disease, fragmenting populations and leaving small unaffected populations at higher risk of extinction if they remain isolated.

Detailed studies of the impact of Ebola virus disease have been conducted on two populations in the Republic of Congo (RC) affected in 2002/2003 and 2004, respectively: the Lossi population (Bermejo et al., 2006) and the Lokoué population [Odzala-Kokoua National Park (Caillaud et al., 2006)]. In these populations, the outbreaks led to more than $80 \%$ reduction in population densities (Bermejo et al., 2006; Devos et al., 2008) and to the disappearance of about $95 \%$ of individuals, affecting more females and immature individuals living in groups than solitary males (Caillaud et al., 2006). The demographic crashes in the 
studied gorilla populations coincided with 1) Ebola epidemics in humans, 2) the occurrence of Ebola infected gorilla carcasses (Rouquet et al., 2005), and 3) was followed by the detection of Ebola virus antibodies in great ape fecal samples in the areas of gorilla population declines (Reed et al., 2014). Although we should be cautious due to the absence of a large diagnostic sample from dead gorillas, these findings led scientists to suspect the Ebola virus to have caused the observed massive declines in gorilla populations (Bermejo et al., 2006; Caillaud et al., 2006; Leroy et al., 2004; Reed et al., 2014; Rouquet et al., 2005; Wittmann et al., 2007), especially in the absence of any other identified threat (e.g., environmental, another undetected emerging disease or intensive poaching). Therefore, although we are aware that Ebola disease as a cause of demographic crash in gorillas is still a hypothesis, we considered this to be the most probable option to explain the observed sudden decline of the studied population, based on past evidence of the effect of emerging diseases on wildlife (Altizer et al., 2003; Daszak et al., 2000). The gorilla population of Lokoué sustained a decrease in breeding group sizes and reduced numbers of adult females per group; characteristics which were no longer detectable six years after the outbreak (Genton et al., 2012; Genton et al., 2015). Other characteristics persisted, such as the absence of large breeding groups with all classes of immature individuals. Outside the Lossi and the Lokoué populations, the impact of Ebola virus disease at a regional scale remains poorly known (Fig. 1). Another population composed of about 400 gorillas observed at Maya Nord in Odzala-Kokoua National Park in 1998 (Magliocca et al., 1999) was suspected to have suffered from an Ebola outbreak because very few indices of gorilla presence were detected in 2004 (M. Douadi and D. Caillaud, personal communication). Post-Ebola nest count surveys were consistent with these observations, supporting a decrease in gorilla density in the northern part of the Park since 2005 (WCS, 2009).

[Figure 1 here] 
Here we investigated the demographic status of populations after Ebola outbreaks and subsequent spatial fragmentation risks on gorilla populations inhabiting the tropical forest of the Odzala region, using a long-term demographic study of neighbouring populations. We used monitoring data gathered from clearings within the forest, because these open areas are highly attractive for gorillas due to high plant mineral contents (Magliocca and Gautier-Hion, 2002), and provide the best conditions to detail the age/sex demographic structure of populations. Our objectives were 1) to test whether the declined population of Lokoué suffered from another demographic crash possibly resulting from an Ebola outbreak during the last decade or was still recovering, 2) and if so to describe its recovery process, 3) to determine if Romani, a spatially close population, was characterized by demographic indicators consistent with the decline expected from an Ebola virus disease. A population affected during the Ebola 2003-2004 outbreak should display a combination of the demographic short-term indicators of a recent Ebola outbreak, highlighted in Genton et al. (2012). These indicators are 1) small proportion of individuals living in groups (compared to solitary individuals), 2) small proportion of adult females and immatures within population, 3) small breeding group size and 4) reduced number of adult females per group, compared to an unaffected population. Additionally, the absence of large breeding groups with all classes of immature individuals, a longer-term indicator, should persist more than six years (Genton et al., 2012). As population size may be affected by other ecological factors than a recent Ebola outbreak, we did not take population size as a relevant marker of a recent Ebola outbreak.

\section{METHODS}

\section{Studied populations and periods}

We studied two gorilla populations visiting clearings in the Odzala-Kokoua National Park. The Lokoué population $\left(00^{\circ} 54^{\prime} 23^{\prime}{ }^{\prime} \mathrm{N}, 15^{\circ} 10^{\prime} 33^{\prime \prime} \mathrm{E}\right)$ is located $100 \mathrm{Km}$ North-East of the 
Lossi reserve (Fig. 1). The Romani population $\left(00^{\circ} 41^{\prime} 28^{\prime \prime N}\right.$; $\left.14^{\circ} 53^{\prime} 31^{\prime \prime E}\right)$ is located between Lossi and Lokoué, $80 \mathrm{Km}$ from Lossi and $20 \mathrm{Km}$ from Lokoué (Fig. 1). We monitored the Lokoué population for fourteen years (2001-2014), and the Romani population for ten years (2005-2014). Hereafter, Ebola outbreak will refer to the period in 2003-2004 when the Ebola virus was detected in the gorilla populations of Odzala Park region. We defined seven siteperiods of observation (hereafter "periods"): at Lokoué, a before Ebola disease period (L-2: 2001-2003), and three periods after the Ebola outbreak (L+2: 2005-2006; L+6: 2008-2010; $\mathrm{L}+10$ : 2013-2014); and at Romani, three periods $(\mathrm{R}+2$ : 2005-2006; $\mathrm{R}+6$ : $2008-2010$; $\mathrm{R}+10$ : 2013-2014, details in Supplementary material Table S1), all after the known Ebola disease period in the region. The Romani population was of unknown demographic status when we started collecting data. 


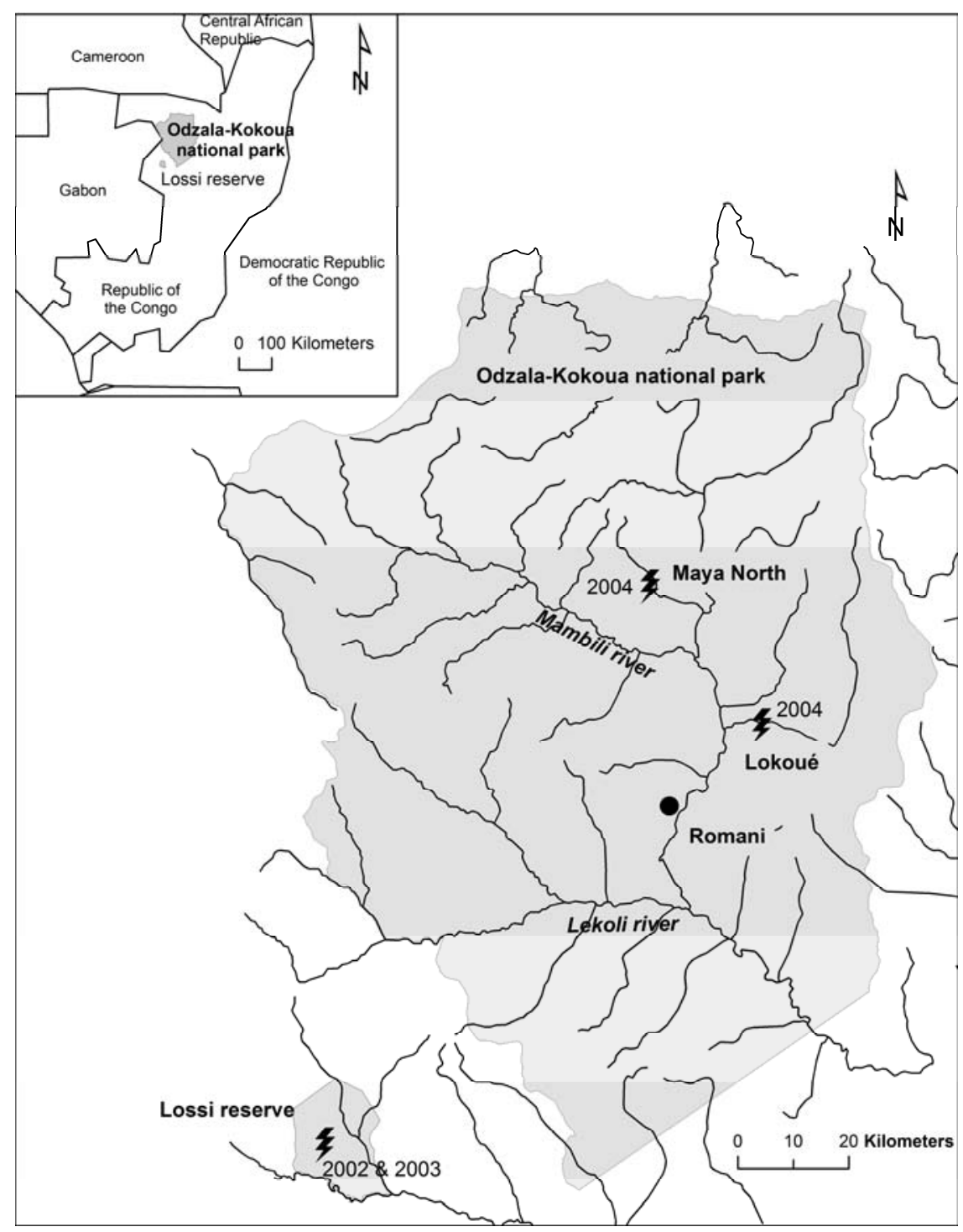

Figure 1. Localisation of Lokoué and Romani study sites in the Odzala-Kokoua National Park (Republic of Congo) and of suspected Ebola-affected sites in the region.

The sites suspected to have been affected by Ebola outbreaks are showed by lightning flash symbols and dates of outbreaks are indicated.

\section{Data collection}

In both populations, we monitored gorillas visiting a clearing, daily, from a 4-meter-high platform located at the edge of the clearing according to the methods described in Genton et al. (2012). The frequency of gorillas visiting the clearings decreased from $94.5 \%$ to less than 
$42 \%$ of observation days at Lokoué after the Ebola outbreak and was around $50 \%$ of observation days at Romani (Supplementary material Table S1). We identified each individual on the basis of a combination of physical features using a Kowa spotting scope (20x60) and a Canon EOS 40D or 60D digital camera equipped with a $600 \mathrm{~mm}$ lens and a Teleplus $2 \mathrm{x}$ converter. We determined sex and age-class based on physical and behavioral criteria as follows (Breuer et al., 2009; Gatti et al., 2004; Genton et al., 2012): infants: $\leq 4$ years old; juveniles: 4 to 7.5 years old; subadults: 7.5 to 10 years old for females, 7.5 to 11 years old for males; adult females: $>10$ years old; adult males: young adult males or “blackbacks": 11 to 14 years old, mature males or "silverbacks"': >14 years old. Hereafter, the term "immatures" refers to females and males up to 10 and 11 years old, respectively. For each gorilla unit, we recorded the unit composition and classified the unit as breeding group, non-breeding group or solitary. Breeding groups contained a silverback male and at least one adult female. Non-breeding groups were typically composed of non-reproductive individuals and did not contain both silverbacks and adult females (Levréro et al., 2006).

\section{Data analyses}

We performed analyses comparing the structure of the Lokoué population ten years after the Ebola outbreak ( $\mathrm{L}+10$ period) with that of the population shortly after the Ebola outbreak $(\mathrm{L}+2)$ and before the Ebola outbreak (L-2) to detect indicators of an additional demographic crash suggesting a new epidemic event or to confirm the recovery process of the population. We also compared the structure of the Romani population for the three study periods $(\mathrm{R}+2, \mathrm{R}+6, \mathrm{R}+10)$ with the Lokoué population before the Ebola outbreak and two years after the Ebola outbreak $(L+2)$, respectively, to examine whether the Romani population presented short-term indicators of a demographic crash that could have been caused by an 
Ebola outbreak. We used the unit composition recorded the last time each unit was observed in each period.

We used generalized linear models (GLMs) with binomial error and logit link function to model the effect of the period on the proportion of adult females and immatures vs. adult males and the proportion of individuals living in groups vs. solitary individuals. We used GLMs with quasi Poisson family error (to account for overdispersion in data) and variance proportional to the cube of the mean to compare count data among periods. Response variables for these models were the size of the breeding groups and the number of adult females per breeding groups. We tested the effect of the period on the different response variables by analyzing the model deviances using Chi-square tests (binomial models) and Ftests (quasi Poisson likelihood models). All tests were performed using an alpha threshold of 0.05. We performed all statistical analyses with $\mathrm{R}$ software version 2.12.2 (R Development Core Team, 2014).

\section{RESULTS}

The Lokoué population included 377 individuals and 76 gorilla units before the Ebola outbreak (L-2 period). After the Ebola outbreak, the Lokoué population size was 38, 40 and 54 individuals (in $\mathrm{L}+2, \mathrm{~L}+6$ and $\mathrm{L}+10$, respectively) belonging to 19,13 and 11 units, respectively. From 2005 to 2014, the Romani population size was 145, 107 and 147 individuals (in $\mathrm{R}+2, \mathrm{R}+6$ and $\mathrm{R}+10$, respectively) belonging to 43,30 and 30 units, respectively (see details in supplementary material Table S2).

At Lokoué, ten years after the outbreak (in $L+10$ ), none of the tested demographic parameters significantly differed from those of the population in the pre-Ebola period (L-2) while values were significantly or near significantly higher compared to the two years postEbola period (L+2, Fig. 2, Table 1). Therefore, all demographic parameters are progressively 
recovering the pre-Ebola values during the ten year period after the outbreak (Fig. 2). However, although the range of breeding group sizes increased (Fig. 2c), including large groups with several classes of immature individuals, the absence of blackback males within groups still persisted (see details in supplementary material Table S3).
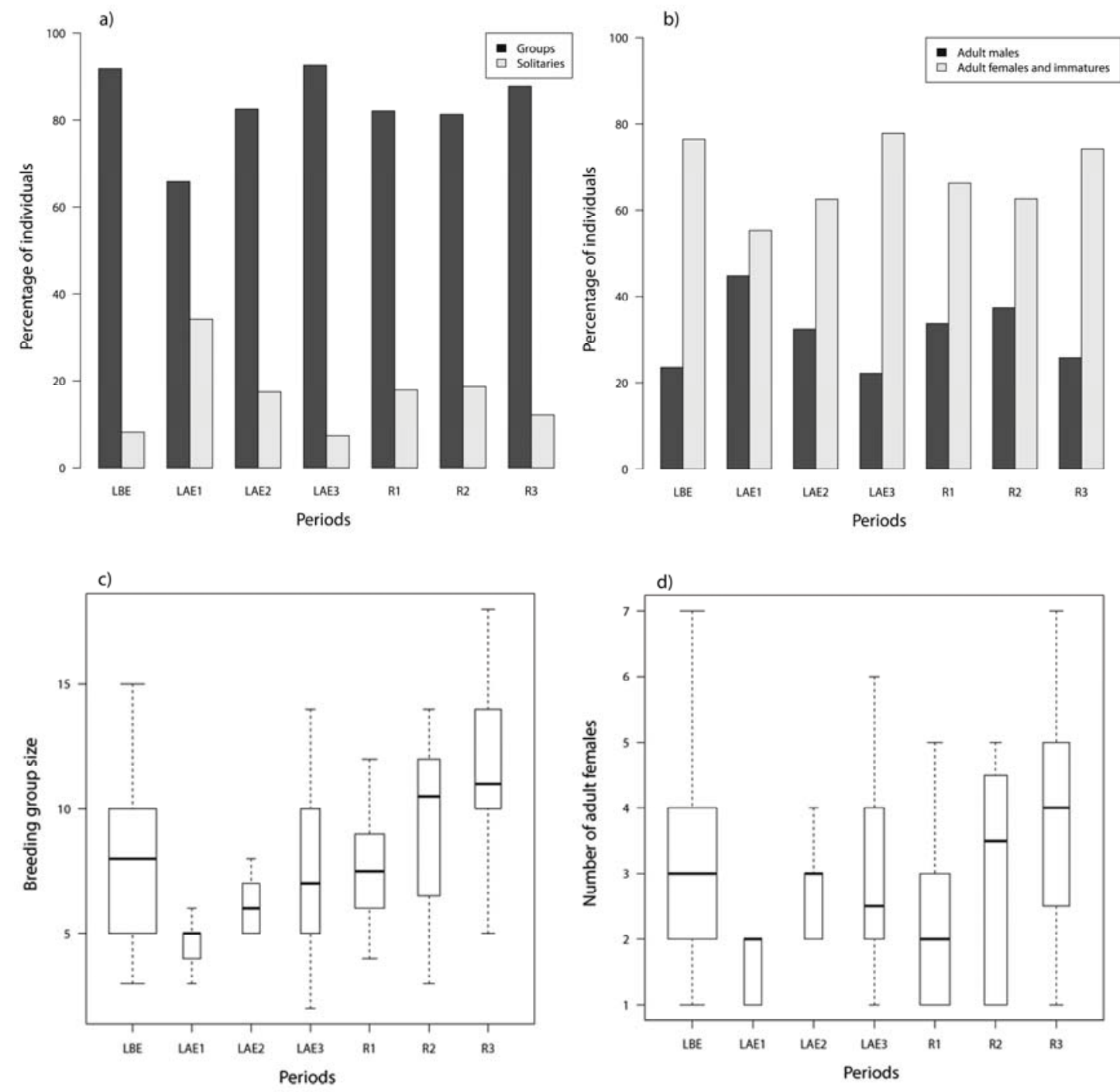

Figure 2. Demographic parameters of interest of the Lokoué and Romani populations at different study periods, a) percentage of individuals living in group vs. solitary individuals; b) age-sex structure; c) boxplots of breeding group sizes; d) boxplots of the number of adult females within breeding groups. 
$\mathrm{L}=$ Lokoué; $\mathrm{R}=$ Romani; $-\mathrm{X}=\mathrm{X}$ years before the suspected Ebola virus outbreaks in 2003$2004 ;+X=X$ years after the suspected Ebola outbreak (see details in Supplementary material Table S1). In boxplots, bold horizontal lines are median values. The width of the boxes varies in proportion to the square roots of the number of observations in the groups. The ends of the vertical lines indicate the minimum and maximum values.

Table 1. Results of the tests of comparisons of dependent demographic variables between periods. Significant values are in bold.

$\begin{array}{lcccccccccc}\text { Compared periods } & & \mathrm{L}+10 & \mathrm{~L}+10 & \mathrm{R}+3 & \mathrm{R}+6 & \mathrm{R}+10 & \mathrm{R}+3 \text { vs. } & \mathrm{R}+6 \text { vs. } & \mathrm{R}+10 \\ & & & \text { vs. L-2 } & \text { vs. L+3 } & \text { vs. L-2 } & \text { vs. L-2 } & \text { vs. L-2 } & \mathrm{L}+3 & \mathrm{~L}+3 & \text { vs. } \mathrm{L}+3 \\ \begin{array}{l}\text { Percentage of } \\ \text { individuals living in } \\ \text { groups }\end{array} & & & & & & & & & & \\ & \text { Chisq } & 0.043 & 10.715 & 9.332 & 8.595 & 1.923 & 4.383 & 3.627 & 9.117 \\ & \text { df } & 85 & 28 & 117 & 104 & 104 & 6 & 47 & 47 \\ & p & 0.836 & \mathbf{0 . 0 0 1} & \mathbf{0 . 0 0 2} & \mathbf{0 . 0 0 3} & 0.166 & \mathbf{0 . 0 3 6} & 0.057 & \mathbf{0 . 0 0 3}\end{array}$

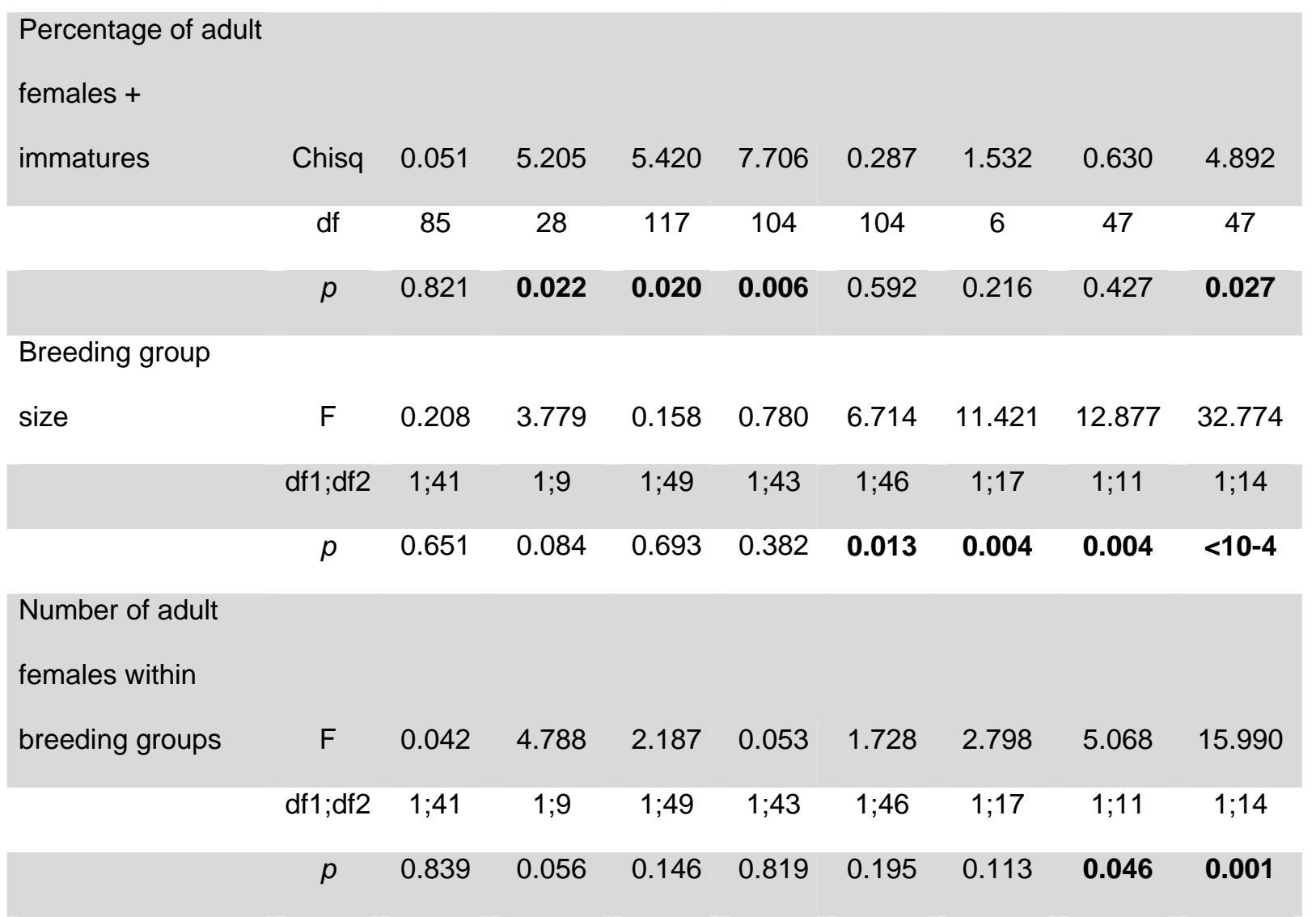


$\mathrm{L}=$ Lokoué; $\mathrm{R}=$ Romani; $-\mathrm{X}=\mathrm{X}$ years before the suspected Ebola virus outbreaks in 2003$2004 ;+X=X$ years after the suspected Ebola outbreak (see details in Supplementary material Table S1). Significant values are in bold.

The Romani population differed from the pre-Ebola outbreak Lokoué population by a significantly smaller proportion of individuals living in groups and a smaller proportion of adult females and immatures during the two first periods $(\mathrm{R}+2$ and $\mathrm{R}+6)$ while differences were no longer detectable in the $\mathrm{R}+10$ period (Fig. 2a,b; Table 1). By contrast, over the entire study, breeding group sizes and the number of adult females within groups did not differ from that at Lokoué before the Ebola outbreak or were even significantly higher (Fig. 2c,d, Table 1). Compared to the Lokoué population two years after Ebola, the Romani population had a significantly or near significantly higher proportion of individuals living in groups and higher breeding group sizes throughout the study (Fig. 2a,c; Table 1). Moreover, it showed a significantly higher proportion of adult females and immatures in $\mathrm{R}+10$ and a higher number of females within breeding groups in $\mathrm{R}+6$ and $\mathrm{R}+10$ (Fig. 2b,d; Table1). In addition, we noticed that at Romani, regardless of the period, as at Lokoué before Ebola, breeding groups included all age classes (see details in Supplementary material Table S3). This is in contrast to Lokoué after the outbreak where no breeding groups included blackback males two, six and even ten years after the Ebola epizootic (see details in Supplementary material Table S3).

\section{DISCUSSION}

\section{Ebola status of the studied populations}

Ten years after the Ebola outbreak, we confirmed the recovery process of the Lokoue population (Genton et al., 2012; Genton et al., 2015). Although the size of that population is increasing slowly, the main short-term demographic signs detected after the Ebola outbreak 
(i.e. small proportion of individuals living in groups, small proportion of adult females and immatures, small breeding group sizes and reduced number of females within breeding groups) were no longer detectable ten years post-outbreak. These results suggest that the Lokoué population has not undergone an additional demographic perturbation over the past decade. However, the absence of blackback males within breeding groups persists, which could be considered as a long-term indicator of large demographic perturbations. This corresponds to the time necessary for the offspring of the breeding groups that were newlyformed after the Ebola outbreak to mature.

At Romani, we did not find the combination of the short-term indicators of a recent (i.e. during the last decade) demographic crash. Indeed, mean breeding group sizes (7.5-11.8 individuals) were in the range of the Lokoué population pre-Ebola (8.2 individuals) and of other presumed unaffected populations [10.7 individuals at Maya North (Magliocca et al., 1999), 8.4 at Mbeli (Parnell, 2002)], while they dramatically differed from the Lokoué two years post-Ebola (4.6). Similarly, the mean number of adult females in breeding groups did not differ from that of the Lokoué population in the pre-Ebola period or from that of other studied populations: 2.3-4.2 at Romani vs. 3.2 at Lokoué, 3.5 at Mbeli (Breuer et al., 2010), and 4 at Maya (Magliocca et al., 1999). Moreover, at Romani as at Lokoué before the Ebola outbreak, we found groups of different ages, including small newly formed groups [“"nascent groups" sensu (Parnell, 2002)], and large mature groups composed of all classes of immatures, especially blackback males. These findings strengthen previous modeling work showing that the Romani population behaved similarly to the Lokoue population before the Ebola outbreak, with regard to survival rates and social dynamic patterns (Genton et al., 2015). The proportion of females and immatures, and the proportion of individuals living in groups, were intermediate between those of the Lokoué population in the pre- and post-Ebola periods, increasing from 2005 to 2014 when they were similar to the unaffected Lokoué 
population. That could suggest a demographic post-Ebola outbreak recovery process. However, these differences more likely reflected variation in population dynamics due to different ecological conditions, notably the number of breeding groups visiting the Romani clearing at that time (from 8 to 14), rather than the occurrence of a recent Ebola virus disease event. Thus, those indicators would not be sufficient alone to reliably detect a recent Ebola outbreak, in the absence of the strongest indicators of a demographic crash following a recent Ebola disease period, namely smaller breeding group sizes, numbers of adult females per breeding group, and the absence of mature breeding groups with all classes of immatures. The smaller size of the Romani population compared to the Lokoué pre-Ebola population could be due to differences in habitat quality between the two sites.

\section{Population fragmentation consequences}

The demographic and epidemiological status of four populations living in the region affected by the Ebola outbreak in 2002-2004 [Lossi (Bermejo et al., 2006); Lokoué (Caillaud et al., 2006; Genton et al., 2012; Genton et al., 2015), this study); Maya North (Genton et al., 2012; Magliocca et al., 1999); Romani (this study)], implies a fragmenting effect of Ebola outbreaks in gorilla populations. In addition to Ebola outbreaks causing a global decline (Junker et al., 2012), the heterogeneous spatial impact could create isolated pockets of unaffected populations. These small populations are more at risk of local extinction due to other pressures such as poaching or forest logging.

Variations in the geographic distribution of Ebola virus reservoirs and in vegetation characteristics were found to be relevant predictors of the zoonotic transmission of the Ebola virus (Alexander et al., 2015; Pigott et al., 2014). At a local scale, it is possible that lower disease risk at Romani compared to close surrounding populations might be associated with landscape characteristics that limit bat densities through the provision of resources (fruits). 
The effects of a heterogeneous landscape on spatial variation in rates of disease or parasite infestations were mentioned in other studies, such as the effect of forest fragmentation on infection prevalence in Red colobus Procolobus rufomitratus (Gillespie and Chapman, 2008), [(see also rabies epidemics in raccoons (Smith et al., 2002) or helminthic infestation in peridomestic rodents (Froeschke and Matthee, 2014)]. These effects could also vary according to host movement behaviors (Phoebe Minh and Waller, 2013; Tracey et al., 2014). Indeed, our results might indicate that, although Ebola outbreaks appeared to have affected large areas, suitable conditions for viral transmission might not have been met at all sites, resulting in a spatially heterogeneous outbreak. We unfortunately are unable to appreciate the extent of this heterogeneity because of the scarcity of censuses and demographic studies at a more regional scale before the detected Ebola outbreaks.

Our study emphasized that emerging disease should not be considered only as a factor decreasing local population size but also as a factor changing population structure and fragmenting populations even if habitat is not destroyed. Therefore, fragmentation of populations should be analyzed through demographic and genetic signatures of outbreaks and not be limited to mapping of suitable habitats. However, the level of population fragmentation in the Odzala region due to Ebola virus disease remains unknown. Ebola disease events that could have occurred at other sites in a period close to 2002-2004 have unfortunately no chance to be detected with demographic indicators anymore. Indeed, indicators of a suspected outbreak are no longer detectable 6 years post-outbreak (Genton et al., 2012) especially in the absence of baseline demographic data.

Consequences of disease-induced fragmentation on population viability will depend, partly, on the capacity of the species to recolonize the habitat. Recolonization may be hampered for species with high social or environmental constraints on dispersal decision. For instance, gorillas of the Romani population, located $20 \mathrm{Km}$ from the Lokoue site, would be unlikely to 
emigrate to the Lokoué region because of the presence of the Mambili river, impassable for gorillas, between the two sites. Spatial structuration of populations post-disease has already been found in Tasmanian devil (Sarcophilus harrisii) populations affected by a facial tumor disease. In this case, the dispersal patterns of females was altered as a consequence of the decline in population density (Lachish et al., 2011). Change in population density is indeed a common factor influencing behavioral decisions to disperse. In our study, the fact that the Lokoué population is slowly recovering is partly due to reduced immigration, which leads us to suspect a severe decrease of surrounding populations at a large scale. Six years after Ebola at Lokoué, the immigration of non-breeders remained lower than before the Ebola outbreak and lower than in the Romani population (Genton et al., 2015). Studies on quantifying immigration and analyzing the socio-environmental factors affecting immigration of both sexes and group formation are needed.

\section{Recommendations for gorilla conservation}

Our study shows that several parameters of the demographic structure of populations can be relevant indicators of recent Ebola outbreaks, however this knowledge requires long-term demographic monitoring. Due to the susceptibility of Western lowland gorillas to the Ebola virus, the large demographic effects and their consequences in terms of local extinction risks and the threat to the species, it is critical to maintain demographic monitoring on affected and surrounding gorilla populations in the Odzala-Kokoua National Park.

We emphasize the importance of considering the preservation of wide areas to allow connectivity between gorilla subpopulations and to allow the recolonization of affected zones through immigration. A high connectivity between subpopulations could favor the spread of directly transmitted pathogens by favoring the dispersal of infected individuals (Hess, 1996). However, a lack of connectivity between local populations could risk driving them to extinction by demographic fluctuations when they are small. Some studies therefore suggest 
that increasing connectivity favors species persistence even if it encourages disease transmission (Altizer et al., 2003; McCallum and Dobson, 2002). Additionally, connectivity may allow dispersal of resistant individuals and limit the low genetic variability due to population bottleneck.

Incorporating data describing social network patterns into modeling approaches would be a promising perspective to better estimate the benefits and costs of connectivity in the risk of disease spreading through populations, as has already been investigated in communities of chimpanzee (Rushmore et al., 2013) and Tasmanian devils (Hamede et al., 2012). This is of special concern in socially structured species such as gorillas. Such studies can help control infectious disease through management actions targeting, for example, vaccinations to the most connected individuals in endangered species (Rushmore et al., 2014). As spatial structuring may modify the contact network in wild gorillas, changes in the level of fragmentation of populations should be introduced in those models.

\section{ACKNOWLEDGMENTS}

We are very grateful to the two anonymous reviewers for their constructive comments. We thank the team of the ECOFAC programme (EU): C. Aveling, B. Djoni-Djimbi, P. Ngouembe, J-M. Froment, P. Marshall, P. Montuir, P. Mortier, P. Rickmounie, T. Smith, J. de Winter and African Parks Networks: D. Zeller, L. Lamprecht for logistic assistance and permission to work in Odzala-Kokoua National Park. We are grateful to J-B. Lepale, S. Yaba Ngouma, D-J Ndebo, A. Lavandier, M. Douadi, D. Caillaud, C. Devos, M. Dewas, L. Bouquier, S. Navel, Q. Gautier, G. Le Flohic, D-M. Paquet, P. Besnard, M. Boros for their assistance with data collection on site. This is a scientific production of UMR CNRS 6553, Caren-OSUR, University of Rennes1. This research was funded by the ECOsystèmes FORestiers programme (http://www.gip-ecofor. org/; Ministère de l'Ecologie et du 
Développement Durable France), the Espèces-Phares programme (DG Environnement, UE, carried out by Réseau des Aires Protégées d'Afrique Centrale; http://www.rapac.org), and the French agency for research via the project ANR-11-JVS7-015 IDi-Pop. We also thank A. Dazé for English editing.

\section{REFERENCES}

Alexander, K. A., Sanderson, C. E., Marathe, M., Lewis, B. L., Rivers, C. M., Shaman, J., . . Eubank, S. (2015). What factors might have led to the emergence of Ebola in West Africa? Plos Neglected Tropical Diseases, 9, e0003652.

Altizer, S., Harvell, D., \& Friedle, E. (2003). Rapid evolutionary dynamics and disease threats to biodiversity. Trends in Ecology \& Evolution, 18, 589-596.

Bermejo, M., Rodriguez-Teijeiro, J. D., Illera, G., Barroso, A., Vila, C., \& Walsh, P. D. (2006). Ebola outbreak killed 5000 gorillas. Science, 314, 1564.

Bode, M., Hawkins, C., Rout, T., \& Wintle, B. (2009). Efficiently locating conservation boundaries: Searching for the Tasmanian devil facial tumour disease front. Biological Conservation, 142, 1333-1339.

Breuer, T., Hockemba, M. B. N., Olejniczak, C., Parnell, R. J., \& Stokes, E. J. (2009). Physical maturation, life-history classes and age estimates of free-ranging Western gorillas-insights from Mbeli bai, Republic of Congo. American Journal of Primatology, 71, 106-119.

Breuer, T., Robbins, A. M., Olejniczak, C., Parnell, R. J., Stokes, E. J., \& Robbins, M. M. (2010). Variance in the male reproductive success of western gorillas: acquiring females is just the beginning. Behavioral Ecology and Sociobiology, 64, 515-528.

Caillaud, D., Levréro, F., Cristescu, R., Gatti, S., Dewas, M., Douadi, M., . . . Ménard, N. (2006). Gorilla susceptibility to Ebola virus: The cost of sociality. Current Biology, 16, R489-R491.

Daszak, P., Cunningham, A. A., \& Hyatt, A. D. (2000). Emerging infectious diseases of wildlifeThreats to biodiversity and human health. Science, 287, 443-449. 
Devos, C., Walsh, P. D., Arnhem, E., \& Huynen, M. C. (2008). Monitoring population decline: can transect surveys detect the impact of the Ebola virus on apes? Oryx, 42, 367-374.

Froeschke, G., \& Matthee, S. (2014). Landscape characteristics influence helminth infestations in a peri-domestic rodent - implications for possible zoonotic disease. Parasites \& Vectors, 7, 393.

Gatti, S., Levréro, F., Ménard, N., \& Gautier, H. A. (2004). Population and group structure of western lowland gorillas (Gorilla gorilla gorilla) at Lokoué, Republic of Congo. American Journal of Primatology, 63, 111-123.

Genton, C., Cristescu, R., Gatti, S., Levréro, F., Bigot, E., Caillaud, D., . . . Ménard, N. (2012). Recovery potential of a Western lowland gorilla population following a major Ebola outbreak: results from a ten year study. Plos One, 7, (e37106) doi:37110.31371/journal.pone.0037106.

Genton, C., Pierre, A., Cristescu, R., Levréro, F., Gatti, S., Pierre, J.-S., . . Le Gouar, P. (2015). How Ebola impacts social dynamics in gorillas: a multistate modelling approach. Journal of Animal Ecology, 84, 166-176.

Gillespie, T. R., \& Chapman, C. A. (2008). Forest fragmentation, the decline of an endangered primate, and changes in host-parasite interactions relative to an unfragmented forest. American Journal of Primatology, 70, 222-230.

Grard, G., Biek, R., Tamfum, J.-J. M., Fair, J., Wolfe, N., Formenty, P., . . . Leroy, E. (2011). Emergence of divergent Zaire Ebola virus strains in Democratic Republic of the Congo in 2007 and 2008. Journal of Infectious Diseases, 204, S776-S784.

Hamede, R., Bashford, J., Jones, M., \& McCallum, H. (2012). Simulating devil facial tumour disease outbreaks across empirically derived contact networks. Journal of Applied Ecology, 49, 447456.

Hawkins, C. E., Baars, C., Hesterman, H., Hocking, G. J., Jones, M. E., Lazenby, B., . . Wiersma, J. (2006). Emerging disease and population decline of an island endemic, the Tasmanian devil Sarcophilus harrisii. Biological Conservation, 131, 307-324.

Hess, G. (1996). Disease in metapopulation models: Implications for conservation. Ecology, 77, 16171632.

IUCN (2008). IUCN red list of Threatened Species. Gland, Switzerland: IUCN. 
Junker, J., Blake, S., Boesch, C., Campbell, G., du Toit, L., Duvall, C., . . Kuehl, H. S. (2012). Recent decline in suitable environmental conditions for African great apes. Diversity and Distributions, 18, 1077-1091.

Kilpatrick, A. M., Briggs, C. J., \& Daszak, P. (2010). The ecology and impact of chytridiomycosis: an emerging disease of amphibians. Trends in Ecology \& Evolution, 25, 109-118.

Lachish, S., Miller, K. J., Storfer, A., Goldizen, A. W., \& Jones, M. E. (2011). Evidence that diseaseinduced population decline changes genetic structure and alters dispersal patterns in the Tasmanian devil. Heredity, 106, 172-182.

LaDeau, S. L., Kilpatrick, A. M., \& Marra, P. P. (2007). West Nile virus emergence and large-scale declines of North American bird populations. Nature, 447, 710-713.

Leendertz, S. A. J., Gogarten, J. F., Dux, A., Calvignac-Spencer, S., \& Leendertz, F. H. (2016). Assessing the Evidence Supporting Fruit Bats as the Primary Reservoirs for Ebola Viruses. Ecohealth, 13, 18-25.

Leroy, E. M., Kumulungui, B., Pourrut, X., Rouquet, P., Hassanin, A., Yaba, P., . . . Swanepoel, R. (2005). Fruit bats as reservoirs of Ebola virus. Nature, 438, 575-576.

Leroy, E. M., Rouquet, P., Formenty, P., Souquiere, S., Kilbourne, A., Froment, J.-M., . . Rollin, P. E. (2004). Multiple Ebola virus transmission events and rapid decline of Central African wildlife. Science, 303, 387-390.

Levréro, F., Gatti, S., Ménard, N., Petit, E., Caillaud, D., \& Gautier-Hion, A. (2006). Living in nonbreeding groups: An alternative strategy for maturing gorillas. American Journal of Primatology, 68, 275-291.

Magliocca, F., \& Gautier-Hion, A. (2002). Mineral content as a basis for food selection by western lowland gorillas in a forest clearing. American Journal of Primatology, 57, 67-77.

Magliocca, F., Querouil, S., \& Gautier-Hion, A. (1999). Population structure and group composition of western lowland gorillas in North-Western Republic of Congo. American Journal of Primatology, 48, 1-14.

McCallum, H., \& Dobson, A. (1995). Detecting disease and parasite threats to endangered species and ecosystems. Trends in Ecology \& evolution, 10, 190-194. 
McCallum, H., \& Dobson, A. (2002). Disease, habitat fragmentation and conservation. Proceedings of the Royal Society Biological Sciences Series B, 269, 2041-2049.

Parnell, R. J. (2002). Group size and structure in western lowland gorillas (Gorilla gorilla gorilla) at Mbeli Bai, Republic of Congo. American Journal of Primatology, 56, 193-206.

Phoebe Minh, T., \& Waller, L. (2013). Effects of landscape fragmentation and climate on Lyme disease incidence in the Northeastern United States. Ecohealth, 10, 394-404.

Pigott, D. M., Golding, N., Mylne, A., Huang, Z., Henry, A. J., Weiss, D. J., . . Hay, S. I. (2014). Mapping the zoonotic niche of Ebola virus disease in Africa. eLife, 3.

R Development Core Team. (2014). A language and environment for statistical computing, reference index version 2.11.1, Vienna, Austria: R Foundation for statistical computing. Retrieved from http://www.R-project.org.

Reed, P. E., Mulangu, S., Cameron, K. N., Ondzie, A. U., Joly, D., Bermejo, M., . . Sullivan, N. J. (2014). A New Approach for Monitoring Ebolavirus in Wild Great Apes. Plos Neglected Tropical Diseases, 8.

Rouquet, P., Froment, J. M., Bermejo, M., Kilbourn, A., Karesh, W., Reed, P., . . . Leroy, E. M. (2005). Wild animal mortality monitoring and human Ebola outbreaks, Gabon and Republic of Congo, 2001-2003. Emerging Infectious Diseases, 11, 283-290.

Rushmore, J., Caillaud, D., Hall, R. J., Stumpf, R. M., Meyers, L. A., \& Altizer, S. (2014). Networkbased vaccination improves prospects for disease control in wild chimpanzees. Journal of the Royal Society $\quad$ Interface, $\quad 11$, http://dx.doi.org/20140310.20141098/rsif.20142014.20140349.

Rushmore, J., Caillaud, D., Matamba, L., Stumpf, R. M., Borgatti, S. P., \& Altizer, S. (2013). Social network analysis of wild chimpanzees provides insights for predicting infectious disease risk. Journal of Animal Ecology, 82, 976-986.

Smith, D. L., Lucey, B., Waller, L. A., Childs, J. E., \& Real, L. A. (2002). Predicting the spatial dynamics of rabies epidemics on heterogeneous landscapes. Proceedings of the National Academy of Sciences of the United States of America, 99, 3668-3672. 
Tracey, J. A., Bevins, S. N., VandeWoude, S., \& Crooks, K. R. (2014). An agent-based movement model to assess the impact of landscape fragmentation on disease transmission. Ecosphere, 5. DOI: $10.1890 / \mathrm{es} 13-00376.1$

Vredenburg, V. T., Knapp, R. A., Tunstall, T. S., \& Briggs, C. J. (2010). Dynamics of an emerging disease drive large-scale amphibian population extinctions. Proceedings of the National Academy of Sciences of the United States of America, 107, 9689-9694.

WCS (2009). Protection and monitoring of great apes in Odzala-Kokoua national Park, Republic of Congo. (Final report to USFWS Great Apes Fund). Congo: WCS.

Wittmann, T. J., Biek, R., Hassanin, A., Rouquet, P., Reed, P., Yaba, P., . . Leroy, E. M. (2007). Isolates of Zaire ebolavirus from wild apes reveal genetic lineage and recombinants. Proceedings of the National Academy of Sciences of the United States of America, 104, $17123-17127$. 


\section{SUPPLEMENTARY MATERIALS}

Table S1. Observation time and presence of gorillas on the Lokoué and Romani clearings during each period of the study.

\begin{tabular}{|c|c|c|c|c|}
\hline $\begin{array}{l}\text { Site } \\
\text { periods }\end{array}$ & Dates & $\begin{array}{l}\text { No days of } \\
\text { observation }\end{array}$ & $\begin{array}{l}\text { No of hours of } \\
\text { observations }\end{array}$ & $\begin{array}{l}\% \text { days of gorilla } \\
\text { presence }\end{array}$ \\
\hline L-2 & $\begin{array}{l}\text { April } 2001 \text { to } \\
\text { September } 2002\end{array}$ & 380 & 3668 & 94.5 \\
\hline$L+2$ & $\begin{array}{l}\text { December } 2004 \\
\text { to May } 2006\end{array}$ & 344 & 3110 & 41.3 \\
\hline$L+6$ & $\begin{array}{l}\text { June } 2008 \text { to } \\
\text { April } 2010\end{array}$ & 253 & 2145 & 22.9 \\
\hline$L+10$ & $\begin{array}{l}\text { February } 2013 \text { to } \\
\text { May } 2014\end{array}$ & 182 & 1638 & 14.8 \\
\hline $\mathrm{R}+2$ & $\begin{array}{l}\text { February } 2005 \text { à } \\
\text { May } 2006\end{array}$ & 287 & 2088 & 62.7 \\
\hline$R+6$ & $\begin{array}{l}\text { June } 2008 \text { à } \\
\text { April } 2010\end{array}$ & 307 & 2767 & 48.2 \\
\hline$R+10$ & $\begin{array}{l}\text { January } 2013 \text { to } \\
\text { May } 2014\end{array}$ & 211 & 2110 & 49.3 \\
\hline
\end{tabular}

$\mathrm{L}=$ Lokoué; $\mathrm{R}=$ Romani ; $\mathrm{X}=\mathrm{X}$ years before the suspected Ebola virus outbreaks in 2003$2004 ;+X=X$ years after the suspected Ebola outbreak. 
Table S2. Structure of Lokoué and Romani populations during each period of the study.

\begin{tabular}{|cccccc} 
Site period & Population size & No of units & \% BG & \% NBG & $\%$ S \\
\hline L-2 & 377 & 76 & 48.7 & 10.5 & 40.8 \\
\hline L+2 & 38 & 19 & 26.3 & 5.3 & 68.4 \\
\hline L+6 & 40 & 13 & 38.5 & 7.7 & 53.8 \\
\hline $\mathrm{L}+10$ & 54 & 11 & 54.5 & 9.1 & 36.4 \\
\hline $\mathrm{R}+2$ & 145 & 43 & 32.6 & 6.9 & 60.5 \\
\hline $\mathrm{R}+6$ & 107 & 30 & 26.7 & 6.6 & 66.7 \\
\hline $\mathrm{R}+10$ & 147 & 30 & 36.7 & 3.3 & 60.0
\end{tabular}

$\mathrm{L}=$ Lokoué; $\mathrm{R}=$ Romani $;-\mathrm{X}=\mathrm{X}$ years before the suspected Ebola virus outbreaks in 2003$2004 ;+X=X$ years after the suspected Ebola outbreak (see details in supplementary material Table S1). BG: breeding groups; NBG: non breeding groups; S: solitary individuals. 
Table S3. Group size and composition [mean number - SD, (range)] of breeding and nonbreeding groups in Lokoué and Romani populations during each period of the study.

\begin{tabular}{|c|c|c|c|c|c|c|c|c|c|}
\hline $\begin{array}{l}\text { Site } \\
\text { periods }\end{array}$ & Group type & Size & SB & $\mathrm{AF}$ & BB & Sub & Juv & Inf & $\mathrm{NI}$ \\
\hline \multirow[t]{4}{*}{ L-2 } & BG & $8.2-3.3$ & $1-0$ & $3.2-1.8$ & $0.2-0.7$ & $1-1$ & $0.8-1.1$ & $2-1.3$ & 0 \\
\hline & $(n=37)$ & $(3-15)$ & $(1-1)$ & $(1-7)$ & $(0-4)$ & $(0-4)$ & $(0-4)$ & $(0-5)$ & \\
\hline & NBG & $5.5-4.4$ & $0.9-0.4$ & 0 & $0.9-1.2$ & $2.3-1.9$ & $1.5-2$ & 0 & 0 \\
\hline & $(n=8)$ & $(2-15)$ & $(0-1)$ & & $(0-3)$ & $(0-5)$ & $(0-6)$ & & \\
\hline \multirow[t]{4}{*}{$L+2$} & BG & $4.6-1.1$ & $1-0$ & $1.6-0.5$ & 0 & $0.6-0.5$ & $0.4-0.9$ & $1-0.7$ & 0 \\
\hline & $(n=5)$ & $(3-6)$ & $(1-1)$ & $(1-2)$ & & $(0-1)$ & $(0-2)$ & $(0-2)$ & \\
\hline & NBG & 2 & 1 & 0 & 0 & 1 & 0 & 0 & 0 \\
\hline & $(n=1)$ & & & & & & & & \\
\hline \multirow[t]{3}{*}{$L+6$} & BG & $6.2-1.3$ & $1-0$ & $2.8-0.8$ & 0 & $0.4-0.5$ & $0.4-0.5$ & $1.2-1.1$ & $0.4-0.9$ \\
\hline & $(n=5)$ & $(5-8)$ & $(1-1)$ & $(2-4)$ & & $(0-1)$ & $(0-1)$ & $(0-2)$ & $(0-2)$ \\
\hline & NBG & 2 & 1 & 0 & 1 & 0 & 0 & 0 & 0 \\
\hline
\end{tabular}

$\begin{array}{rlcccccccc} & (\mathrm{n}=1) \\ \mathrm{L}+10 & \text { BG } & 7.5-4.1 & 1-0 & 3.0-1.9 & 0 & 0.5-0.8 & 1.2-0.8 & 2.0-1.9 & 0 \\ & (\mathrm{n}=6) & (2-14) & (1-1) & (1-6) & & (0-2) & (0-2) & (0-5) \\ & \text { NBG } & 5 & 1 & 0 & 1 & 2 & 1 & 0 & 0\end{array}$

$\begin{array}{rlllllllll} & (n=1) \\ R+2 & B G & 7.5-2.3 & 1-0 & 2.4-1.3 & 0.6-0.9 & 1.5-1.1 & 1.4-1.5 & 0.9-1.0 & 0\end{array}$

\begin{tabular}{|c|c|c|c|c|c|c|c|c|c|}
\hline & $(n=14)$ & $(4-11)$ & $(1-1)$ & $(1-5)$ & $(0-3)$ & $(0-4)$ & $(0-4)$ & $(0-2)$ & \\
\hline & NBG & $3.3-1.2$ & 0 & $0.3-0.6$ & $1-1$ & $0.3-0.6$ & $1.3-1.2$ & $0.3-0.6$ & 0 \\
\hline & $(n=3)$ & $(2-4)$ & & $(0-1)$ & $(0-2)$ & $(0-1)$ & $(0-2)$ & $(0-1)$ & \\
\hline$R+6$ & BG & $9.0-4.0$ & $1-0$ & $2.9-1.6$ & $1.1-2.1$ & $1.3-1.2$ & $1.1-1.5$ & $1.6-1.4$ & 0 \\
\hline & $(n=8)$ & $(3-14)$ & $(1-1)$ & $(1-5)$ & $(0-6)$ & $(0-3)$ & $(0-4)$ & $(0-4)$ & \\
\hline & NBG & $6.0-5.6$ & $0.5-0.7$ & 0 & $2.0-2.8$ & $3.5-2.1$ & 0 & 0 & 0 \\
\hline
\end{tabular}




$\begin{array}{rlcccccccc} & (n=2) & (2-10) & (0-1) & & (0-4) & (2-5) & & & \\ R+10 & \text { BG } & 11.8-3.9 & 1-0 & 3.7-1.8 & 0.8-1.5 & 1.2-0.8 & 1.6-1.9 & 2.5-1.8 & 0 \\ & (n=11) & (5-19) & (1-1) & (1-7) & (0-5) & (0-2) & (0-6) & (0-6) & 0 \\ & \text { NBG } & 2 & 0 & 0 & 1 & 1 & 0 & 0 & 0 \\ & (n=1) & & & & & & & & \end{array}$

SB: Silverback, AF: Adult Female, BB: Blackback, Sub: Subadult, Juv: Juvenile, Inf: Infant, NI: Non Identified. BG: breeding groups; NBG: non breeding groups. L = Lokoué; $\mathrm{R}=$ Romani ; $\mathrm{X}=\mathrm{X}$ years before the suspected Ebola virus outbreaks in 2003-2004; $+\mathrm{X}=\mathrm{X}$ years after the suspected Ebola outbreaks (see details in Table S1). 